\title{
PENGARUH LITERASI KEUANGAN TERHADAP PERILAKU KEUANGAN MAHASISWA PROGRAM STUDI PENDIDIKAN EKONOMI UNIVERSITAS PAMULANG
}

\section{BADRUS SHOLEH}

\author{
Dosen Pendidikan Ekonomi, Universitas Pamulang
}

dosen00901@unpam.ac.id

\begin{abstract}
ABSTRAK
Penelitian ini untuk mengetahui apakah terdapat pengaruh signifikan literasi keuangan terhadap perilaku keuangan mahasiswa Pendidikan Ekonomi Universitas Pamulang tahun akademik 2019/2020. Populasi Penelitian ini adalah mahasiswa semester VII yakni 339 mahasiswa, Pengambilan sampel dilakukan dengan teknik simple random sampling sebanyak 113 mahasiswa. Penelitian ini dengan pendekatan kuantitatif, dalam pengumpulan menggunakan angket dan analisis data menggunakan statsistik deskriptif serta regresi linear sederhana. Hasil penelitian menunjukkan bahwa terdapat pengaruh yang signifkan antara literasi keuangan terhadap perilaku keuangan mahasiswa semester VII Pendidikan Ekonomi Unversitas Pamulang tahun akademik 2019/2020.
\end{abstract}

Kata kunci : Literasi Keuangan, perilaku keuangan

Literasi keuangan akhir-akhir menjadi salahsatu fokus perhatian dalam beberapa studi penelitian, hal ini terjadi karena masyarakat Indonesia literasi keuangannya masyarakat masih belum maksimal. OJK (otoritas jasa keuangan) dalam surveinya tahun 2016 bahwa masyarakat Indonesia tingkat literasi keuangan 29,7 persen (tempo, Februari 2019). Apabila dibandingkan dengan negara tetangga apabila Indonesia dibandingkan dengan negara tetangga terkait literasi keuangan negara dikawasan sekitar ASEAN, seperti pada tahun 2016 negara Malaysia tingkat literasi keuangannya mencapai 81 persen dari populasi total pendudukanya, sedangkan Thailand 78 persen dari penduduknya dan negara singapura 96 persen dari penduduknya (liputan6.com). Dari gambaran tersebut menunjukkan tingkat literasi keuangan penduduk Indonesia masih cukup jauh dari dari tiga negara tetangga tersebut. Survei terbaru yang dilakukan oleh OJK pada survei nasional literasi keuangan ketiga pada tahun 2019 dari survei bahwa 38,03 persen indeks literasi 
keuangan dari tahun sebelumnya mengalami peningkatan, Pada tahun 2016 yang hanya sebesar 29,7 persen (kompas.com). Trend dari tahun ke tahun mengalami peningkatkan positif, namun dibanding negaranegara sekitar ASEAN literasi masyarakat Indonesia masih perlu ditingkatkan lagi.

Era kehidupan modern seperti saat ini yang salahsatu cirinya ditandai dengan digitalisasi diberbagai sektor, tak terkecuali sektor ekonomi. Kehidupan ekonomi masyarakat erat kaitannya dengan digital. Perkembangan teknologi yang semakin pesat saat ini juga memacu perilaku konsumsi sebagian masyarakat yang irasional, keadaan tersebut berdampak dalam kehidupan secara tidak langsung mempengaruhi konsumsi masyarakat diikuti masifnya iklan-iklan di media massa serta perilaku berbelanja menggunakan teknologi digital untuk yang memberikan kemudahan setiap orang untuk bertransaksi dan berpengaruh terhadap gaya hidup dan pola konsumsi masyarakat menghadapi terpaan iklan dan kemudahan dalam bertransaksi di era digital. Dengan adanya fenomena tersebut maka dibutuhkan kecerdasan finansial seseorang dalam menyikapi tantangan tersebut tersebut terutama dalam pengelolaan keuangan.

Mahasiswa Pendidikan

Ekonomi Universitas Pamulang dihadapkan pada permasalahan keuangan, mereka harus benar-benar mampu mengelola uang yang mereka miliki selain untuk kebutuhan pendidikan, juga berkaitan dengan kebutuhan pribadi masing-masing. Era digital sedikit banyak mempengaruhi masyarakat dalam berkonsumsi begitupula yang terjadi pada konsumsi mahasiswa, karena di era digital merubah pola konsumsi mahasiswa dengan kemudahan teknologi yang dapat digunakan. Mahasiswa harus cerdas mengelola keuangan mereka untuk kebutuhan pribadi sehari-hari maupun kebutuhan untuk dana pendidikan. Kecakapan mereka dalam mengelola kekeuangan atau perilaku keuangan yang mereka lakukan sehari hari erat kaitannya dengan pengetahuan keuangan (melek keuangan) yang mereka miliki masing. Mahasiswa harus bertanggung jawab terhadap keputusan dalam mengelola keuangan yang mereka ambil masing-masing agar tidak terjadi masalah keuangan. Menurut Cheung et al dalam Faidah (2019) menjelaskan bahwa timbulnya masalah keuangan penyebabnya adalah rendahnya literasi keuangan.

Literasi keuangan merupakan hal yang penting bagi mahasiswa, seperti dalam penelitian Ramavhea et al (2017) apabila mahasiswa membuat keputusan yang tidak tepat dan mereka menemukan kesulitan keuangan dalam diri mereka, kemungkinan akan berdampak 
negatif pada pengalaman belajar mereka, dan pada akhirnya meningkatkan tingka drop out yang tinggi, hal ini menunjukkan bahwa mahasiswa perlu memiliki literasi keuangan dan ketrampilan agar proses belajar mereka berhasil. Lebih lanjut menurut Marcolin dan Abraham dalam Hadzic \& Poturak (2014) menemukan studi tentang literasi keuangan mahasiswa di Universitas telah mempresentasikan secara umum mahasiswa yang berlatarbelakang jurusan bisnis lebih melek keuangan daripada mahasiswa yang bukan berlatar belakang jurusan bisnis, namun demikan belum ada upaya yang telah dilakukan untuk melacak pengetahuan keuangan dan ketrampilan ketika mahasiswa siswa sedang menyelesaikan studi mereka, selain itu belum ada upaya untuk menghubungkan tingkat literasi keuangan seseorangan dengan berbagai disiplin ilmu.

Dari gambaran di atas disimpulkan bahwa pemahaman literasi keuangan mahasiswa salahsatunya dilatar belakangi oleh jurusan yang diambil mahasiswa yang diambil saat mereka menempuh studi. Menurut Hamdani (2018) agar terhindar dari masalah keuangan individu harus memiliki literasi keuangan, masalah keuangan terjadi karena individu tidak kurang memiliki pemahaman terkait pengetahuan keuangan dan terbiasa dengan buruknya pengetahuan keuangan. Dari uraian tersebut literasi keuangan dapat menghindarkan seseorang dari masalah keuangan.

Terdapat beberapa definisi mengenai literasi keuangan. Kumar dkk (2017) Literasi keuangan yaitu semua tentang bagaimana individu dapat mengelola uangnya dengan menggunakan pengetahuan mereka tentang keuangan itu sendiri. Literasi keuangan menurut Kozina dan Ponikvar dalam Isomidinova dan Singh (2017) kegiatan kuangan sebagai sebuah komponen modal manusia untuk meningkatkan kesejahteraan individu. Dari uraian diatas disimpulkan bahwa literasi keuangan berupa pengetahuan seseorang terkait mengelola keuangannya, dengan literasi keuangan yang dimiliki berdampak terhadap peningkatan kesejahteraannya.

Literasi keuangan dibutuhkan dalam kehidupan sehari-hari, karena manusia merupakan mahluk ekonomi (homo economicus) yang berusaha memenuhi kebutuhan sehari hari dan bertindak secara rasional salahsatunya berkaitan dengan perilaku keuangan. Menurut Miller, Godfrey, Levesque dan Stark dalam Coskun et al (2019) menekankan pentingnya literasi keuangan di negara-negara berkembang, mereka berpendapat bahwa literasi keuangan akan berdampak pada negara-negara tersebut secara positif melalui dua 
saluran yakni: 1) dengan membantu seseorang membuat keputusan keuangan yang sehat dan dengan demikian menjaga keuangan tetap sehat dan 2) dengan mengenalkan akses keuangan, hal tersebut akan menguatkan fungsi pasar keuangan dan memperkuat ekonomi. Lebih lanjut menurut Atikson dan Messy dalam Shen et al (2018) literasi keuangan selain meningkatkan kemampuan seseorang dalam membuat keputusan terinformasi, meningkatan rasa percaya diri sehingga dapat meningkatkan kemampuan seseorang dengan mudah dapat mengakses layanan keuangan formal.

Perilaku keuangan erat kaitannya dengan penerapan literasi keuangan. Menurut Claulagain (2017) Perilaku keuangan merupakan bagian dari penerapan literasi keuangan yang diyakini secara positif memiliki dampak pada kesejahteraan keuangan seseorang, secara bertahap, perilaku sadar seseorang tersebut menunjukkan dalam pengambilan keputusan, membandingkan biaya peluang serta mencari alternatif dalam meminimalisasi pemborosan. Hal serupa juga diperkuat oleh Dudchyk et al (2019) Populasi atau masyarakat yang memiliki literasi keuangan dan memiliki kompetensi merupakan kunci menuju negara yang makmur, masyarakat disebuah negara yang memiliki dana yang signifikan penggunaan yang efektif yang mengarah pada peningkatan kesejahteraan warga negara yang pada akhirnya memiliki dampak yang positif pada iklmi dinegara, di Ukrania literasi keuangan diajarkan di sekolah keuangan khusus, dan beberapa sekolah biasa yang diteliti atau dijadikan eksperimen terkait literasi keuangan.

Ada beberapa tantangan yang dihadapi dalam literasi keuangan, menurut Mitchell et al (2016) tantangan utama literasi keuangan adalah pada tingkat mikro, meso dan makro yakni terlalu patuh pada industri keuangan, kurangnya pengetahuan keuangan, terlalu percaya diri pada pengetahuan keuangan, kurangnya inisiatif dari pemerintah, kerangka kerja dan aturan, kurangnya perencanaan pada siklus kehidupan dan kurangnya cara-cara yang menarik untuk mengajarkan literasi keuangan.

\section{METODE PENELITIAN}

Pendekatan dalam penelitian ini yakni kuantitatif, dengan jenis penelitian yang digunakan adalah asosiasi. Populasinya adalah seluruh mahasiswa semester VII yang berjumlah 339 Mahasiswa. Sampel penelitian berjumlah 113, dengan teknik simple random sampling, sampel diambil dengan cara tersebut karena dianggap homogen anggota populasinya. Variabel peneltian ini yakni literasi keuangan (X) dan perilaku keuangan (Y). Uji prasyarat 
regresi linear yakni uji normalitas dan linearitas Analisis data berupa analisis deskriptif dan regresi linear sederhana.

Chen dan volpe (1998), Kemal (2014) dalam Suryanto (2018) mengemukakan bahwa terdapat indikator dalam Literasi keuangan, adapaun indikatornya yaitu pengetahuan secara umum tentang keuangan pribadi, pinjaman dan simpanan, investasi serta asuransi.

Perilaku keuangan menurut Nababan dan Sadalia (2013) adapun indikatornya membayar tagihan tepat pada waktunya, menyusun anggaran atau budget dan pengeluaran belanja, melakukan pencatatatan pengeluaran, menyiapkan dana untuk pengeluaran yang tidak terduga, rutin menabung dan sebelum membeli membandingkan harga.

\section{HASIL DAN PEMBAHASAN}

Berikut hasil temuan dan pembahasan penelitian dibawah ini:

\section{Statistik Deskriptif}

Berdasarkan hasil temuan responden menjawaban untuk variabel literasi keuangan jawabannya dengan rata-rata tertinggi mean 4.2920 pada indikator pengetahuan umum pribadi tentang keuangan, dengan pernyataan penghasilan seseorang mempengaruhi tingkat konsumsi yang dilakukan. Sedangkan dengan rata-rata terendah dengan mean 3.0442 pada indikator investing, dengan pernyataan saya memahami bentuk-bentuk risiko obligasi.

Berdasarkan hasil temuan jawaban responden untuk variabel perilaku keuangan, diketahui ratarata tertinggi dengan mean 4.1593 pada indikator membandingkan harga sebelum membeli dengan pernyataan saya selalu berbelanja dengan harga barang paling terjangkau. Sedangkan rata-rata terendah dengan mean 3.1858 dengan indikator membuat anggaran pengeluaran dan belanja dengan pernyataan tidak pernah membuat anggaran pengeluaran belanja harian secara rutin.

Dalam analisis stastistik parametrik menurut Priyanto (2014) uji normalitas data bagian syarat pokok yang harus dipenuhi. One Sample Kolmogorov-Smirnov Test, digunakan dalam pengujian normalitas data dengan yang memiliki tingkat error sebesar 0,05. Dalam penelitian menganalisis uji normalitas diketahui bahwa apabila tingkat signifikan > 0,05 maka data yang diperoleh akan terdistribusi secara normal. Sedangkan apabila diperoleh nilai signifikan $<0,05$ maka dapat diketahui bahwa data tidak terdistribusi secara normal. Berdasarkan hasil penelitian dapat diketahui bahwa hasil pengolahan data uji normalitas pada variabel literasi keuangan diperoleh nilai signifikan sebesar 0,849 hal ini dapat disimpulkan bahwa literasi keuangan 
mahasiswa prodi pendidikan ekonomi terdistribusi secara normal. Sementara itu pada variabel perilaku keuangan mahasiswa prodi pendidikan ekonomi diketahui bahwa nilai signifikan sebesar 0,417 , dari hasil tersebut diketahui bahwa perilaku keuangan mahasiswa prodi pendidikan ekonomi semester VII terdistribusi secara normal. Berdasarkan olah data dihasilkan diketahui bahwa variabel literasi keuangan dan perilaku keuagan mahasiswa prodi pendidikan ekonomi di semester VII dapat dinyatakan data yang digunakan dalam penelitian ini telah berdistribusi normal.

Uji linearitas ini digunakan untuk mengetahui data tersebut memiliki hubungan yang linear atau tidak memiliki hubungan linear, hal digunakan sebagai persyaratan dalam analisis regresi linear sederhana. Analisis data uji linearitas dihasilkan diatas pada output anava table, diketahui nilai sign. Deviation from linearity sebesar 0.139. karena nilai sign. $0.139>0,05$. Dari hasil tersebut dapat disimpulkan bahwa terdapat hubungan yang linear antara varibel literasi keuangan dengan variabel perilaku keuangan pada mahasiswa prodi pendidikan ekonomi di semester VII.

Selanjutnya peneliti melakukan pengolahan data pada analisis regresi linear sederhana. Dimana analisis regresi linear sederhana ini digunakan untuk mengetahui apakahan terdapat pengaruh atau tidak nya antara literasi keuangan dengan perilaku keuangan mahasiswa. adapun hasil perhitungan statistik dalam analisis regresi linear sederhana hasilnya sebagai berikut:

Tabel 1. Hasil Analisis Regrsi Linear Sederhana

\begin{tabular}{|c|c|c|c|c|c|}
\hline \multicolumn{6}{|c|}{ Coefficients $^{\mathrm{a}}$} \\
\hline \multirow[b]{2}{*}{ Model } & \multicolumn{2}{|c|}{ Unstandardized Coefficients } & \multirow{2}{*}{\begin{tabular}{|c|} 
Standardized Coefficients \\
Beta
\end{tabular}} & \multirow[b]{2}{*}{$\mathrm{t}$} & \multirow[b]{2}{*}{ Sig. } \\
\hline & $\mathrm{B}$ & Std. Error & & & \\
\hline $1 \quad$ (Constant) & 29.747 & 6.396 & & 4.651 & .000 \\
\hline $\begin{array}{l}\text { LITERASI } \\
\text { KEUANGAN }\end{array}$ & .563 & .089 & .516 & 6.341 & .000 \\
\hline
\end{tabular}

a. Dependent Variable: PERILAKU KEUANGAN

Sumber : Olah data primer,2019

Hasil persamaan regresi linear sederhana berdasarkan tabel ouput sebagai berikut :

$$
\mathrm{Y}=29.747+0,563
$$

Nilai koefisien regresi yang berdasarkan terlihat pada tabel 1 dari persamaan tersebut, terlihat Nilai Konstanta sebesar 29.747 artinya bahwa apabila literasi keuangan dianggap konstan nilai perilaku keuangan mahasiswanya adalah 29.747, nilai koefisien regresi 
Literasi keuangan sebesar 0,563, diartikan apabila literasi keuangan ditingkatkan sebesar satu tingkatan, dampaknya perilaku keuangan meningkat berupa sebesar 0,563 satuan.

$$
\text { Selanjutnya peneliti }
$$

melakukan uji t, untuk mengetahui apakah terdapat pengaruh yang signifikan baik secara parsial antara variabel literasi keuangan terhadap variabel perilaku keuangan. Untuk mengatahui pengaruh variabel literasi keuangan dapat diketahui bila nilai sig. $\leq 0,05$ maka hipotesis diterima. Namun sebaliknya bila, jika nilai sig. > 0,05 maka hipotesis yang kita peroleh ditolak.
Berdasarkan tabel 1. Diketahui bahwa terdapat pengaruh yang signifikan antara literasi keuangan dan perilaku keuangan pada mahasiswa. Hal ini terdapat dari hasil pengolahan data yaitu diketahi bahwa nilai sig. $0,000<0,05$ maka dapat disimpulkan bahwa Hipotesis diterima, sehingga literasi keuangan memiliki berpengaruh terhadap perilaku keuanga secara signifikan.

Uji Koefisien determinasi $\left(\mathrm{R}^{2}\right)$ digunakan untuk mengukur besarnya tingkat kemampuan yang menjelaskan variabel literasi keuangan dan perilaku keuangan. Hasil koefisien $\mathrm{R}^{2}$ disajikan dalam tabel 2 dibawah ini:

Tabel 2. Hasil Uji Koefisien Determinasi $\left(\mathrm{R}^{2}\right)$

\begin{tabular}{|l|r|r|r|r|}
\hline Model & R & R Square & Adjusted R Square & Std. Error of the Estimate \\
\hline 1 & $.516^{\mathrm{a}}$ & .266 & .259 & 9.73430 \\
\hline
\end{tabular}

Dari tabel 3 diatas, menunjukkan hasil regresi $R$ Square sebesar 0,266. Data ini menunjukkan bahwa Literasi keuangan memiliki kontribusi sebesar $26,60 \%$ terhadap perilaku keuangan dan sisa nya $73,40 \%$ dipengaruhi faktor lain yang tidak diteliti dalam penelitian ini seperti intensitas keuangan, manajemen keuangan mahasiswa dan lain sebagainya.

\section{Pengaruh Literasi Keuangan terhadap Perilaku Keuangan}

Tedapat pengaruh yang signifikan antara Literasi Keuangan dengan Perilaku Keuangan hal ini dibuktikan dari nilai $\mathrm{t}$ sebesar 6.341 yang artinya semakin tinggi tingkat literasi keuangan mahasiswa maka semakin tinggi juga berperilaku keuangan mahasiswa atau semakin berhati-hati dalam mengelola keuangan. Temuan tersebut dikuatkan oleh beberapa temuan 
penelitian terdahulu, seperti temuan Laily (2013) bahwa terdapat pengaruh literasi keuangan terhadap perilaku keuangan yang memiliki pengaruh langsung terhadap perilaku keuangan mahasiswa, Semakin tinggi pengetahuan serta kemampuan yang dimiliki oleh mahasiswa dalam mengelola keuangannya semakin bijak dalam pengelolaan keuangan. Lebih lanjut temuan dari Andarsari dan Ningtyas (2019) bahwa literasi keuangan berpengaruh positif terhadap perilaku keuangan, apabila semakin tinggi seseorang memiliki pengetahuan maka semakin bijak pula perilaku keuangan mereka, pengetahuan keuangan dibutuhkan sebagai dasar dalam keseharian kehidupannya. Temuan Pulungan (2017) menyatakan bahwa terdapat literasi keuangan memiliki pengaruh positif terhadap perilaku keuangan.

Pendidikan erat hubungannya dengan Literasi keuangan, karena dalam pendidikan diajarkan pengetahuan terkait tentang keuangan, berbekal literasi keuangan yang dimiliki, Seseorang dapat berperilaku secara bijak dan rasional dalam mengambil keputusan keuangan atau dalam mengelola keuangannya, karena perilaku keuangan merupakan salahsatu bentuk atau implementasi dari seseorang terkait tingkat literasi keuangan yang dimilikinya. Terdapat temuan penelitian yang menunjukkan pendidikan memiliki peranan penting tingkat literasi seseorang. Pendidikan mempunyai peranan penting dalam literasi keuangan, karena lewat pendidikan diajarkan pengetahuan berkaitan tentang keuangan, pendidikan tidak hanya formal namun juga pendidikan non formal bahkan informal (keluarga). Pendidikan juga merupakan salahsatu penentu tingkat literasi keuangan seseorang, dengan pendidikan keuangan maka akan meningkatkan literasi keuangan seseorang, dengan literasi keuangan yang dimiliki maka akan berdampak atau berpengaruh pada perilaku keuangan seseorang. Beberapa temuan penelitian terkait dengan pendidikan keuangan antara lain temuan dari Kumar et al (2017) perilaku keuangan dipengaruhi oleh literasi keuangan yang memiliki dampak pada keputusan anak-anak sehingga pemahaman yang baik tentang masalah keuangan hendaknya diberikan orang tua terhadap anak-anak mereka yang dapat mempengaruhi perilaku keuangan terhadap keputusan yang dibuat.

Temuan serupa juga oleh Widayati (2012) bahwa keluarga merupakan tempat sosialisasi tentang masalah keuangan yang paling dominan. Selain hal tersebut, tingkat literasi keuangan juga dapat digunakan sebagai dasar dalam pengambilan kebijakan oleh pemangku kepentingan, seperti 
temuan Gaisina dan Kaidarova (2017) temuan literasi keuangan di pedesaan Kazakhstan menjadi informasi yang berguna dan dapat digunakan oleh politisi untuk merancang langkah-langkah melindungi keuangan rumah tangga pada masyarakat pedesaan. Menurut temuan Rootman dan Antoni (2014) Pendidikan keuangan diperlukan untuk meningkatkan literasi keuangan, inklusi keuangan dan perilaku keuangan. Literasi keuangan akan menjadikan seseorang rasional dalam mengambil keputusan keuangan.

\section{KESIMPULAN}

Berdasarkan pembahasan penelitian diatas, disimpulkan bahwa sebagai berikut:

a. Gambaran varibel literasi keuangan untuk indikator tertinggi yakni pengetahuan umum mengenai keuangan pribadi yakni berkaitan tentang penghasilan seseorang mempengaruhi tingkat konsumsi yang dilakukan, sedangkan indikator terendah pada indikator investing yakni berkaitan pemahaman tentang pemahaman bentuk-bentuk risiko obligasi.

b. Gambaran variabel perilaku keuangan indikator tertinggi yakni membandingkan harga sebelum membeli yakni berkaitan dengan selalu berbelanja dengan harga paling terjangkau, sedangkan indikator terendah indikator membuat anggaran pengeluaran dan belanja berkaitan dengan tidak pernah membuat anggaran pengeluaran belanja harian secara rutin.

c. Terdapat pengaruh signifikan antara literasi keuangan yang dimiliki mahasiswa dengan perilaku keuangan yang dapat teraplikasikan oleh mahasiswa semester VII Prodi Pendidikan Ekonomi Universitas Pamulang tahun akademik 2019/2020.

\section{REFERENSI}

Andarsari, Pipit Rosita dan Mega Noerman Ningtyas. (2019). The Role of Financial on Financial Behavior. Journal of Accounting and Business Education, 4(1), 24-33

Chaulagain, Ramesh Prasad. (2017). Relationship Between Financial Literacy and Behavior of Small Borrowers. NRB Economic Review, 29 (3), 33-55.

Coskun, Ali, Muhammed Abdullah Sahin, Alperen Zengin. (2019). Financial Literacy in Turkey : A Field Study To Touch Based With the OECD. International Journal of Research in Business and Social Science, 8(3)

Dudchyk, Oksana, Iryna Matvijchuk, Mariia Kovinia, Tetiana Salnykova, Iryna Tubolets. (2019). Financial Literacy In 
Ukraine: From Micro To Macro Level. Investment Management And Financial Innovations, 16(4) , 240-253.

Faidah, Faridatun. (2019). Pengaruh Literasi Keuangan dan Faktor Demografi Terhadap Minat Investasi Mahasiswa. Journal of Applied Business and Economic, 5(3), 251-263.

Gaisina, Sholpan dan Lyazzat Kaidarova. (2017). Financial Literacy Of Rural Population as a determinant of Saving Behavior in Kazakhstan. Rural Sustainbility Research, 38(33)

Hadzic, Minela \& Mersid Poturak. (2014). Students Perception About Financial Literacy: Case Study of International Burch University. Europan Researcher, 77(6-2), 1155-1166. Hamdani, Mailani. (2018). Analisis

Tingkat Literasi Keuangan dan Pengaruhnya Terhadap Perilaku Keuangan Pada Mahasiswa Prodi Manajemen Universitas Terbuka, Jurnal Bakti Masyarakat. 1(1), 139-145.

Isomidinoiva, Gulnoza, Jugindar Singh Kartar Sing. (2017). Determinants of Financial Literacy: a Quantitative Study Among Young Students in Tashkent Uzbekistan. Electronic Journal Business and Management, 2(1), 61-75.

Kumar, suresh, Christalita watung, Josephine Eunike N, Lusianaa
Liunata. (2017). The Influence Financial Literacy Towards Financial Behavior and its Implication on Financial Decisions: A Survei of President University Student in CikarangBekasi. FIRM Journal of Management Studies, 2(1) .

Mitchell, Jan W\& Magipervas E Abusheva. (2016). The Actual Challenges of Financial Literacy, SHS Web Conference, 28, 1-4.

Nababan, D., \& Sadalia, I . (2013). Analisis Personal Financial Literacy dan Financial Behavior Mahasiswa Strata I Fakultas Ekonomi Universitas Sumatera Utara. Jurnal Media Informasi Manajemen, 1(1), 1-15.

Nujmatul, Laily. (2013). Pengaruh Literasi Keuangan Terhadap Perilaku Mahasiswa dalam Mengelola Keuangan. Journal of Accounting and Business Education, 2(4)

Priyatno, Dwi. (2014). SPSS 22: Pengolah Data Praktis. Yogyakarta: Penerbit Andi.

Pulungan, Delyana R. (2017).Literasi

Keuangan dan Dampaknya terhadap Perilaku Keuangan Masyarakat Kota Medan. Jurnal Ilmu Ekonomi dan Studi Pembangunan, 17(1), 56-61

Ramahvea, G, Jaco Fouche, Freda Van Der Walt. (2017). Financial Literacy Under Graduate Students- A Case Study of A 
Public University In South Africa. International Journal of Economic and Finance Studies, 9 (2), 48-65.

Rootman, Chantal \& Xolile Antoni. (2014). Investigating Financial Literacy To Improve Financial Behaviour Among Black Consumers. Journal of Economic and Financial Sciences, 8(2), 474-494.

Shen, Yan, Wenxiu Hu, C James Hueng. (2018). The Effects of Financial Literacy, Digital Financial Product Usage and Internate Usage on Financial Inclusion in China. Matec web conferences

Suryanto dan Mas Rasmini. (2018). Analisis Literasi Keuangan dan Faktor-faktor yang Mempengaruhinya (Survey Pada Pelaku Usaha Mikro, Kecil, dan Menengah di Kota Bandung.). Jurnal Ilmu Politik dan Komunikasi, 8 (2)

Widayati, Irin. (2012). Faktor-faktor yang Mempengaruhi Literasi Finansial Mahasiswa Fakultas Ekonomi dan Bisnis Universitas Brawijaya. Asset: Jurnal Akuntansi dan Pendidikan, 1(1), 88-99.

https://www.ojk.go.id/id/berita-dankegiatan/siaranpers/Pages/Siaran-Pers-SurveiOJK-2019-Indeks-Literasi-DanInklusi-KeuanganMeningkat.aspx https://bisnis.tempo.co/read/1178611 /ojk-literasi-dan-inklusikeuangan-masyarakat-indonesiarendah/full\&view $=$ ok https://money.kompas.com/read/201 9/11/08/145542226/survei-ojk2019-indeks-literasi-dan-inklusikeuangan-meningkat https://www.liputan6.com/bisnis/rea d/2589471/literasi-keuanganindonesia-kalah-dari-malaysia 